\title{
PENERAPAN PENDEKATAN KETERAMPILAN PROSES UNTUK MENINGKATKAN HASIL BELAJAR IPA SISWA KELAS V
}

\author{
A A Sagung Putra Mas Dewi ${ }^{*}$, Ni Wayan Rati² \\ 1 Universitas Pendidikan Ganesha \\ 2Universitas Pendidikan Ganesha
}

\begin{abstract}
Abstrak
Penelitian ini bertujuan untuk mengetahui peningkatan belajar IPA dengan penerapan pendekatan keterampilan proses untuk meningkatkan hasil belajar IPA siswa kelas V semsester ganjil SD No. 2 Kapal tahun pelajaran 2016/2017. Penelitian ini adalah penelitian tindakan kelas yang dilaksanakan dalam dua siklus. Setiap siklus terdiri atas tahap perencanaan, pelaksanaan tindakan, observasi/evaluasi, dan refleksi. Subjek penelitian ini adalah siswa kelas V di SD No. 2 Kapal, sebanyak 34 orang siswa. Data yang dikumpulkan dianalisis dengan menggunakan metode tes objektif. Data yang didapatkan dari metode tes selanjutnya dianalisis dengan teknik deskriptif kuantitatif. Hasil penelitian menunjukan bahwa, pada siklus I rata-rata hasil belajar IPA siswasebesar 69,41\% pada kategori cukup dan meningkat menjadi $84 \%$ pada siklus II yang berada pada kategori tinggi. Terjadi peningkatan sebesar $14,59 \%$.
\end{abstract}

\author{
Keywords: \\ Pendekatan \\ Keterampilan Proses, \\ Hasil Belajar IPA, SD No. \\ 2 Kapal
}

\section{Pendahuluan}

Penyelenggaraan pendidikan dinyatakan sebagai suatu proses pembudayaan dan pemberdayaan peserta didik yang berlangsung sepanjang hayat, dimana dalam proses tersebut harus ada pendidik yang memberikan teladan dan mampu membangun kemauan, serta mengembangkan potensi dan kreativitas peserta didik. Prinsip tersebut menyebabkan adanya pergeseran paradigma proses pendidikan, dari paradigma pengajaran ke paradigma pembelajaran. Proses pembelajaran pada satuan pendidikan hendaknya dilaksanakan secara interaktif, inspiratif, menyenangkan, menantang, memotivasi peserta didik untuk berpartisipasi aktif, serta memberikan ruang yang cukup bagi prakarsa, kreativitas dan kemandirian sesuai dengan bakat, minat dan perkembangan fisik serta psikologis peserta didik. Tugas dan peran guru bukan lagi sebagai pemberi informasi tetapi sebagai pendorong belajar agar siswa dapat mengkonstruksi sendiri pengetahuannya melalui kegiatan pembelajaran. Proses pendidikan tidak terlepas dari kegiatan belajar mengajar di kelas.

Kegiatan belajar mengajar sangat ditentukan oleh kerjasama antara guru dan siswa. Guru dituntut untuk mampu menyajikan materi pelajaran dengan optimal. Oleh karena itu diperlukan kreativitas dan gagasan yang baru untuk mengembangkan cara penyajian materi pelajaran di sekolah. Kreativitas yang dimaksud adalah kemampuan seorang guru dalam memilih metode, pendekatan, dan media yang tepat dalam penyajian materi pelajaran. Perkembangan pembelajaran Ilmu Pengetahuan Alam (IPA) khususnya di sekolah dasar yang terletak di daerah-daerah pedesaan dengan fasilitas dan tenaga pendidik yang minim, membuat peran guru sebagai pemberi informasi dan pendorong aktivitas belajar cenderung tidak tercapai secara maksimal. Pembelajaran yang diperoleh di kelas cenderung tidak utuh dan tidak berorientasi tercapainya standar kompetensi dan kompetensi dasar. Pembelajaran lebih bersifat teachercentered, guru hanya menyampaikan IPA sebagai produk dan peserta didik menghafal informasi faktual. Peserta didik hanya mempelajari IPA pada domain kognitif yang terendah. Peserta didik tidak dibiasakan untuk mengembangkan potensi berpikirnya. Fakta di lapangan menunjukkan bahwa banyak peserta didik yang cenderung menjadi malas berpikir secara mandiri. Cara berpikir yang dikembangkan dalam kegiatan belajar belum menyentuh domain afektif dan psikomotor. Alasan yang sering dikemukakan oleh para guru adalah keterbatasan waktu, sarana, lingkungan belajar, dan jumlah peserta didik per kelas yang terlalu banyak.

Pesatnya perkembangan IPA dan teknologi dalam berbagai bidang kehidupan, menuntut guru untuk mampu menyelenggarakan pembelajaran IPA yang menarik, efektif dan efesien untuk menyiapkan peserta didik yang melek IPA dan teknologi, mampu berpikir kritis, logis, kreatif, serta dapat

* Corresponding author.

E-mail Addresses: agungsagungputradewi.com (A A Sagung Putra Mas Dewi), ni_wayanrati@yahoo.com (Ni Wayan Rati) 
berargumentasi dengan benar (Sri Sulistiyorini, 2007). Dalam kenyataan, tidak banyak peserta didik yang menyukai bidang kajian IPA, karena dianggap sukar dengan keterbatasan kemampuan peserta didik. Namun demikian, guru tetap harus menyelenggarakan sistem pembelajaran IPA yang menarik, efektif, dan efesien.

Selama proses pembelajaran Ilmu Pengetahuan Alam (IPA) di kelas V SD No 2 Kapal dengan menggunakan Kurikulum Tingkat Satuan Pendidikan (KTSP) pada awal semester ganjil tahun pelajaran 2016/2017 masih ditemui beberapa permasalahan. Dari hasil wawancara dengan guru mata pelajaran IPA pada hari selasa 20 September 2016 diketahui terdapat beberapa permasalahan. Masalah tersebut antara lain: sulitnya memberikan pemahaman tentang suatu konsep baru kepada siswa, beberapa materi dalam IPA merupakan hafalan sehingga sulit menyampaikan materi tersebut kepada siswa, tanpa adanya alat peraga akan sangat sulit menyampaikan suatu konsep atau materi dan pemberian contoh-contoh abstrak saja tanpa menghadirkan benda-benda kongkrit terlebih dahulu ke hadapan siswa menyebabkan kesulitan dalam pemahaman suatu konsep.

Berdasarkan hasil observasi yang dilaksanakan dengan melakukan pengamatan langsung terhadap proses pembelajaran IPA di kelas V SD No 2 Kapal, diketahui bahwa guru kurang menguasai konsep materi yang akan diajarkan, selain itu guru kesulitan memancing minat belajar siswa serta pendekatan pembelajaran yang digunakan oleh guru tidak optimal. Semangat siswa kurang dalam belajar, sehingga menyebabkan aktivitas siswa dalam mengikuti pembelajaran sangat rendah, hanya siswa yang pandai yang menunjukkan aktivitas belajar baik, sedangkan siswa yang lain hanya diam saja. Siswa cenderung menghafalkan konsep-konsep IPA yang dipelajarinya tanpa memahami dengan benar. Ketika melakukan pencatatan dokumen pada daftar nilai mata pelajaran IPA siswa kelas V SD No 2 Kapal, hasil belajar siswa pada mata pelajaran Ilmu Pengetahuan Alam (IPA) di awal semester ini baru mencapai ratarata 73, sedangkan nilai yang ditetapkan dalam Kriteria Ketuntasan Minimum (KKM) adalah 75. Dari 34 orang siswa kelas V di SD No 2 Kapal, sebanyak 24 siswa belum mencapai nilai KKM, hanya 10 orang siswa yang mampu mencapai nilai KKM.

Berdasarkan refleksi diri, maka ada beberapa permasalahan sebagai penyebab rendahnya hasil belajar IPA siswa, yaitu: 1) masih menggunakan model pembelajaran konvensional dalam membelajarkan siswa. Hal ini akan mengakibatkan siswa menjadi pasif karena pembelajaran didominasi oleh guru. Pembelajaran seperti ini akan membuat siswa tidak termotivasi untuk mengikuti proses pembelajaran karena mereka beranggapan bahwa materi yang diajarkan terlalu abstrak dan sulit untuk dimengerti, 2) dalam mengajar hanya menggunakan satu sumber belajar. Hal tersebut akan mengakibatkan kemampuan siswa menjadi terbatas sehingga akan berdampak pada rendahnya hasil belajar IPA siswa, 3) sulit melibatkan siswa secara aktif dalam proses pembelajaran sehingga aktivitas siswa menjadi pasif, 4) sebagian besar siswa menganggap bahwa IPA adalah pelajaran menghapal, membosankan, dan kurang menantang. Hal tersebut mengindikasikan bahwa guru memperkenalkan IPA hanya sebatas dimensi produk saja, dengan mengabaikan dimensi proses dan dimensi sikap ilmiah, dan 5) siswa kurang dibiasakan bekerja dalam kelompok, sehingga terdapat kecenderungan yang pintar akan semakin pintar dan yang kurang akan semakin kehilangan kesempatan untuk mengembangkan kompetensi yang dimilikinya.

Proses pembelajaran IPA seharusnya menekankan pada pemberian pengalaman secara langsung pada siswa untuk mengembangkan berbagai kompetensi sehingga siswa dapat menemukan sendiri konsep materi pelajaran yang sedang mereka pelajari ataupun memperdalam pemahaman siswa tentang alam sekitar (Julianto, dkk 2011; Juniati \& Widiana, 2017). Menurut Mariana dan Praginda (2009) dalam proses pembelajaran IPA, siswa sebagai ahli sains perlu berlatih meniru ahli sains untuk mengungkap rahasia alam, menjelaskan berbagai fenomena alam yang terjadi di lingkungan sekitarnya, sehingga siswa perlu untuk berinteraksi secara langsung dengan sumber belajar.

Dari identifikasi masalah di atas maka perlu dilaksanakan penelitian tindakan kelas dengan menerapkan suatu pendekatan pembelajaran. Pendekatan pembelajaran Ilmu Pengetahuan Alam (IPA) yang sesuai dengan kondisi di atas adalah Pendekatan Keterampilan Proses. Pendekatan keterampilan proses merupakan salah satu pendekatan yang diharapkan mampu melibatkan siswa secara aktif dalam pembelajaran Ilmu Pengetahuan Alam (IPA) (Oka Sugiarta, dkk., 2016).

Dimyati dan Mudjiono (2002) mengatakan bahwa pendekatan keterampilan proses dapat diartikan sebagai wawasan atau anutan pengembangan keterampilan-keterampilan intelektual, sosial dan fisik yang bersumber dari kemampuan-kemampuan mendasar yang pada prinsipnya telah ada pada diri siswa. Dengan demikian, menggunakan keterampilan proses dalam suatu pembelajaran, akan menyebabkan terjadinya interaksi antara konsep/prinsip/teori yang telah ditemukan. Berdasarkan interaksi tersebut akan timbul sikap dan nilai meliputi ketelitian, kreatif, ketekunan, tenggang rasa, tanggung jawab, kritis, obyektif, rajin, jujur, terbuka dan disiplin, yang diperlukan dalam penemuan ilmu pengetahuan (Lie, 2004). 
Menurut Aisyah (2008) keunggulan pendekatan keterampilan proses di dalam proses pembelajaran, antara lain adalah: (1) siswa terlibat langsung dengan objek nyata sehingga dapat mempermudah pemahaman siswa terhadap materi pelajaran, (2) siswa menemukan sendiri konsepkonsep yang dipelajari, (3) melatih siswa untuk berpikir lebih kritis, (4) melatih siswa untuk bertanya dan terlibat lebih aktif dalam pembelajaran, (5) mendorong siswa untuk menemukan konsep-konsep baru, (6) memberi kesempatan kepada siswa untuk belajar menggunakan metode ilmiah.

Adapun kelemahan dari pendekatan proses yang diungkapkan oleh (Marjain, 2012) yaitu sangat sulit untuk menyusun bahan pelajaran yang berpangkal pada keterampilan tersebut tetapi memenuhi tuntutan bahan pelajaran yang diperlukan siswa dan sesuai dengan lingkungannya serta memberi aktivitas keterampilan proses sains berdampak positif bagi siswa.

Hasil penelitian Harefa (2011) menyimpulkan bahwa dengan menerapkan pendekatan keterampilan proses dapat meningkatkan aktivitas dan hasil belajar siswa pada materi kubus dan balok di Kelas VIII SMP Negeri 1 Tuhemberua. Selanjutnya Emilia (2012) mengungkapkan bahwa kesimpulan yang didapat dari hasil analisis data dan pembahasan adalah pembelajaran matematika dengan menggunakan pendekatan keterampilan proses melalui metode penemuan terbimbing berjalan dengan baik dan dapat meningkatkan aktivitas siswa serta ketuntasan hasil belajar siswa khususnya pada materi keliling dan luas lingkaran. Menurut Samatowa, (2006) beberapa keunggulan pendekatan keterampilan proses yaitu: a)siswa terlibatr langsung dengan objek nyata sehingga dapat mempermudah pemahaman siswa, b) Siswa menemukan sendiri konsep - konsep yang telah dipelajari, c) Melatih siswa untuk berfikir lebih aktif dalam pembelajaran, d) Mendorong siswa untuk menemukan konsep - konsep baru.

Dengan adanya keterampilan proses sains pada model pembelajaran tersebut maka siswa tidak anya sekedar mencari informasi melainkan ikut bekerja untuk memperoleh informasi tersebut. Hal ini menyebab kan siswa aktif. Selain itu dengan adanya keterampilan proses sains membuat siswa mempelajari proses dan produk ilmu pengetahuan sekaligus serta dapat menumbuhkembangkan sikap ilmiah siswa (Juni Anggarawati, dkk. 2013)

Melalui pendekatan keterampilan proses, guru membimbing dan mengarahkan siswa untuk mengembangkan sikap dan nilai melalui proses belajar mengajar serta mengaktifkan siswa sehingga mampu menumbuhkan sejumlah keterampilan tertentu pada diri mereka. Semua kegiatan yang dilakukan dalam pembelajaran diarahkan pada perolehan hasil belajar siswa dari pengalaman dan pengamatan lingkungan yang diolah menjadi suatu konsep yang diperoleh dengan jalan belajar aktif melalui keterampilan proses.

\section{Metode}

Jenis penelitian yang digunakan adalah penelitian tindakan kelas (PTK) atau sering disebut classroom action research. Penelitian tindakan kelas merupakan suatu bentuk penelitian yang bersifat reflektif oleh pelaku tindakan yang dilakukan untuk meningkatkan kemantapan rasional dari tindakantindakan guru dalam melaksanakan tugasnya. (Agung, 2010)

Dalam model PTK ini ada empat tahapan pada satu siklus penelitian. Keempat tahapan tersebut terdiri dari: perencanaan, tindakan, observasi/evaluasi, dan refleksi (Agung, 2005). Subjek penelitian ini adalah siswa kelas V SD No 2 Kapal Tahun Pelajaran 2016/2017 berjumlah 34 orang terdiri 17 siswa perempuan dan 17 siswa laki - laki. Sedangkan objek penelitian ini adalah hasil belajar IPA siswa dengan penerapan pendekatan keterampilan proses. Penelitian tindakan kelas ini dilaksanakan di SD No 2 Kapal, Kecamatan Mengwi, Kabupaten Badung tahun pelajaran 2016/2017 pada mata pelajaran IPA.

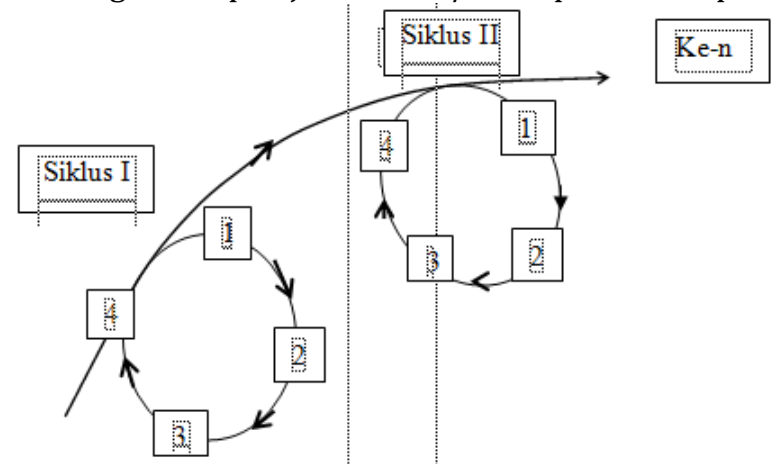

Gambar 1. Model PenelitianTindakan Kelas Beberapa Siklus 
Dalam kegiatan PTK ini, penelitian dilakukan bekerjasama dengan guru mitra terutama guru IPA dan Kepala Sekolah dalam membuat suatu kesepakatan baik dalam menentukan jadwal, pendekatan pembelajaran yang digunakan dalam penelitian. Guru mitra dimohon bantuannya untuk ikut membantu dalam observasi pada saat pelaksanaan penelitian. Penelitian ini adalah peneliitian tindakan kelas yang terdiri dari dua siklus, masing-masing siklus terdiri atas perencanaan, tindakan, observasi/evaluasi dan refleksi. Adapun rancangan penelitian ini dapat dilihat pada Gambar 1.

Pengumpulan data dalam penelitian ini menggunakan metode tes. Data yang dikumpulkan dalam penelitian ini adalah data hasil belajar IPA siswa dengan menggunakan tes hasil belajar. Dalam penelitian tindakan kelas digunakan analisis statistik deskriptif yang bertujuan untuk menentukan tinggi rendahnya hasil belajar IPA yang dikonversikan ke dalam PAP skala lima. Untuk mengetahui tingkat pencapaian hasil belajar IPA digunakan pedoman sebagai berikut.

Tabel 1 Pedoman Konversi PAP Skala Lima Tentang Tingkatan Hasil Belajar IPA

\begin{tabular}{cccc}
\hline Hasil Belajar & Nilai Angka & Nilai Huruf & Predikat \\
\hline $90-100$ & 4 & $\mathrm{~A}$ & Sangat Tinggi \\
$80-89$ & 3 & $\mathrm{~B}$ & Tinggi \\
$65-79$ & 2 & $\mathrm{C}$ & Cukup Tinggi \\
$55-64$ & 1 & $\mathrm{D}$ & Rendah \\
$0-54$ & 0 & $\mathrm{E}$ & Sangat Rendah \\
\hline
\end{tabular}

Kriteria yang digunakan untuk menentukan keberhasilan dalam penelitian ini adalah Penelitian ini dianggap berhasil atau siklus dihentikan jika telah memenuhi kriteria peneltian sebagai berikut: Terjadi peningkatan hasil belajar pada mata pelajaran IPA siswa kelas V dengan standar ketuntasan yang sudah ditetapkan di sekolah yaitu Kriteria Ketuntasan Minimal (KKM) 75 untuk setiap siswa dengan ketuntasan klasikal $\geq 75$ \%.Jika indikator kriteria keberhasilan telah tercapai maka penelitian ini dapat dihentikan, hasil penelitian akan dijadikan pembahasan dan simpulan bahwa siklus tersebut telah tercapai dengan baik

\section{Hasil dan pembahasan}

Penelitian tindakan kelas dilaksanakan di kelas V SD No 2 Kapal. Jumlah siswa kelas V di SD No 2 Kapal adalah 34 orang, yang terdiri dari 17 orang perempuan dan 17 orang laki-laki. Pelaksanaan pembelajaran di dalam kelas, secara umum telah berlangsung sesuai dengan rencana pembelajaran yang telah disusun sebagai penerapan Pendekatan Keterampilan Proses. Penelitian dilaksanakan dalam 2 siklus untuk dua Standar Kompetensi (SK) yaitu memahami cara tumbuhan hijau membuat makanan dan mengidentifikasi cara makhluk hidup menyesuaikan diri dengan lingkungannya.

Dalam penelitian ini data yang dikumpulkan, yaitu data tentang hasil belajar siswa kelas $\mathrm{V}$ pada mata pelajaran IPA. Data hasil beajar siswa kelas V diambil dengan menggunakan tes evaluasi diakhir siklus 1 dan 2. Data yang telah dikumpulkan dianalisis sesuai dengan teknik analisis data yang telah ditetapkan sebelumnya.

Kegiatan penelitian tindakan kelas ini merupakan kolaborasi bersama guru bidang studi, sehingga penelitian ini dapat berjalan dengan lancar. Sebelum memulai kegiatan pembelajaran guru menyampaikan gambaran umum tentang rencana kegiatan pembelajaran yang akan dilakukan dengan menerapkan pendekatan pembelajaran keterampilan proses kepada siswa. Guru juga menyampaikan tentang teknik penilaian yang dilaksanakan selama proses pembelajaran, yang mencakup hasil belajar IPA. Hasil belajar dinilai dengan tes evaluasi di akhir setiap siklus.

Kegiatan siklus I kemudian dilakukan refleksi secara umum untuk mengetahui seberapa besar keberhasilan tindakan yang dilakukan pada siklus tersebut. Serta untuk melihat hambatan-hambatan yang terjadi di dalam pelaksanaan tindakan. Hambatan tersebut misalnya kurangnya minat siswa dalam belajar IPA, dan kurangnya fasilitas yang tersedia di sekolah. Dari hambatan-hambatan yang muncul selama pelaksanaan tindakan kemudian dicarikan solusi dengan menetapkan tindakan baru yang lebih efektif, sebagai alternatif tindakan perbaikan pada siklus berikutnya. Beberapa solusi yang dapat kami terapkan antara lain menarik minat siswa untuk belajar IPA yaitu dengan menciptakan suasana belajar dimana siswa diajak terlibat langsung dalam melakukan praktikum IPA.

Berdasarkan pada hasil analisis data seperti yang diuraikan sebelumnya, selanjutnya diadakan refleksi. Pada tahap refleksi diketahui bahwa sudah terjadi peningkatan pada setiap pertemuan, walaupaun tidak terlalu tinggi, namun jika dilihat dari peningkatan aktivitas maupun hasil belajar pada 
setiap pertemuan terus mengalami peningkatan, siswa yang pada awalnya tidak menunjukkan aktivitas sama sekali saat pertemuan pertama, mengalami perubahan pada pertemuan selanjutnya, siswa tersebut mau menjawab pertanyaan walaupun jawabannya masih kurang tepat. Dalam hasil belajar pada pertemuan pertama, juga mengalami peningkatan pada pertemuan selanjutnya, hal ini disebabkan karena siswa sudah mau memperhatikan penjelasan materi dan ikut serta dalam percobaan yang dilakukan. Karena data hasil penelitian belum memenuhi kriteria keberhasilan yang telah ditargetkan, yaitu untuk kriteria keberhasilan aktivitas belajar minimal kategori tinggi untuk setiap siswa dengan persentase $\geq 75 \%$ sedangkan untuk kriteria hasil belajar adalah memenuhi KKM yaitu 75 untuk setiap siswa dengan ketuntasan klasikal $\geq 75 \%$. Berdasarkan pada data siklus I diatas yang masih belum tercapai secara maksimal, maka penelitian perlu dilanjutkan ke siklus II. Hal tersebut disebabkan karena beberapa hal yang ditemukan pada siklus I, antara lain: 1) Tidak semua siswa mau aktif dalam melakukan percobaan, ada beberapa siswa yang hanya melihat saja tanpa mau ikut serta dalam percobaan, 2) Dalam diskusi kelompok, siswa masih kelihatan kurang aktif berdiskusi bersama teman kelompoknya, 3) Baik itu bertanya, menjawab, mengemukakan pendapat kepada kelompoknya masing-masing maupun kepada guru, siswa masih banyak yang belum berani untuk mengajukan pendapatnya karena belum terbiasa, 4) Terdapat beberapa siswa yang tidak mau maju ke depan saat ditunjuk dalam kegiatan demonstrasi, karena masih merasa malu dan belum terbiasa.

Dengan demikian, maka perlu dicarikan alternatif penyelesaian untuk mengatasi permasalahan yang muncul pada siklus I yang kemudian disempurnakan pada siklus II. Perbaikan tindakan yang dilakukan adalah sebagai berikut: 1) Memberikan pengarahan kepada siswa untuk ikut aktif dan bekerja sama dalam melakukan kegiatan percobaan. 2) Memberikan penguatan kepada siswa yang sudah berani mengajukan pendapat agar lebih ditingkatkan, memberikan motivasi kepada siswa yang masih belum aktif. 3) Memberikan motivasi belajar kepada siswa baik secara individu maupun kelompok, agar berani menyampaikan pendapatnya dalam proses pembelajaran.

Melalui perbaikan proses pembelajaran dan pelaksanaan tindakan siklus I, maka pada pelaksanaan siklus II telah tampak adanya peningkatan proses pembelajaran yang diperlihatkan melalui peningkatan dan hasil belajar siswa. Selama pelaksanaan tindakan siklus II diperoleh hal- hal sebagai berikut: 1) Semua siswa mau aktif dalam melakukan percobaan. 2) Siswa sudah aktif dalam berdidkusi bersama teman kelompoknya 3) Sudah banyak siswa yang berani untuk mengajukan pendapatnya karena sudah terbiasa. 4) Siswa sudah mau maju ke depan saat ditunjuk dalam kegiatan demonstrasi karena sudah tidak malu dan sudah terbiasa.

Penelitian Tindakan Kelas (PTK) yang dilaksanakan dalam dua siklus ini memperoleh data hasil penelitian siklus I dan II bahwa terjadi peningkatan hasil belajar siswa kelas VI SD No. 2 Kapal. Rekapan data hasil belajar IPA siswa kelas V SD No. 2 Kapal yang mengalami peningkatan dapat dilihat dalam bentuk tabel dan diagramberiku:

Tabel 2. Persentase Hasil Belajar IPA Siswa Kelas V SD No. 2 Kapal

\begin{tabular}{ccc}
\hline Aspek yang Diteliti & Siklus I & Siklus II \\
\hline Hasil belajar IPA & $69,41 \%$ & $84 \%$ \\
Ketuntasan Belajar & $50 \%$ & $100 \%$ \\
\hline
\end{tabular}

Penerapan pendekatan pembelajaran keterampilan proses, berkolaborasi dengan guru mata pelajaran IPA kelas V, guru mata pelajaran membantu untuk melakukan observasi selama proses pembelajaran dengan menggunakan lembar observasi yang telah dibuat dalam tahap perencanaan. Observasi tersebut bertujuan untuk mengetahui hasil belajar siswa yang muncul atau terjadi selama proses pembelajaran IPA berlangsung.

Pendekatan pembelajaran keterampilan proses pertama kali diterapkan di kelas V SDNo 2Kapal dalam proses pembelajaran IPA. Hal ini terlihat pada siklus I, siswa merasa senang akan adanya kegiatan percobaan, demonstrasi,kerja kelompok dan penghargaan kelompok. Pada siklus I, terlebih dahulu menyiapkan bahan pembelajaran dan segala sesuatu yang mendukung pelaksanaan penelitian. Semua persiapan dilakukan dalam tahap perencanaan. Setelah tahap perencanaan selesai kemudian dilanjutkan dengan pelaksanaan tindakan, evaluasi/observasi dan yang terakhir refleksi dari pelaksanaan pembelajaran.

Hasil observasi yang dilakukan pada siklus I, masih ada beberapa siswa yang kurang memperhatikan materi pelajaran yang telah diberikandan masih ada siswa yang kurang aktif dalam pembelajaran baik itu dalam menjawab pertanyaan, diskusi kelompok, dan kerjasama dalam kelompok. Selain itu, masih ada beberapa siswa yang mencapai nilai dibawah KKM dan persentase rata-ratakelas secara klasikal masih belum dapat mencapai kriteria keberhasilan yang telah ditetapkan, sehingga harus dilanjutkan ke siklus II. 
Berdasarkan hasil observasi pada siklus II, siswa sudah mulai aktif dalam proses pembelajaran, hal ini terbukti dengan siswa benar-benar memperhatikan materi pelajaran yang dibahas, aktif dalam kegiatan percobaan dan demonstrasi serta aktif dalam kerja kelompok dan juga berusaha menjawab pertanyaan-pertanyaan yang diberikan maupun menanggapi hasil kerja masing-masing kelompok.

Dilihat dari data tersebut, maka hasil belajar siswa kelas V SDNo 2 Kapal pada siklus II telah mencapai kriteria keberhasilan yang ingin dicapai yaitu aktivitas belajar siswa telah meningkat dan berada pada kategori tinggi untuk setiap siswa dengan persentase lebih dari atau sama dengan $75 \%$ dan nilai hasil belajar siswa sama dengan atau lebih dari KKM yang ditentukan oleh sekolah sebesar 75 dengan persentase hasil belajar secara klasikal sama dengan atau lebih dari 75\%.

Penelitian dihentikan pada siklus II, karena pada siklus II telah diperoleh data bahwa hasil belajar siswa telah mencapai kriteria keberhasilan yang sudah ditentukan melalui penerapan pendekatan pembelajaran keterampilan proses dalam pembelajaran IPA siswa kelas V semester ganjilSDNo 2 Kapal tahun pelajaran 2016/2017 yaitu semua siswa telah mencapai KKM dengan ketuntasan belajar 100\%.

Berdasarkan pada hal tersebut di atas, membuktikan bahwa penerapan pendekatan pembelajaran keterampilan proses mampu meningkatkan aktivitas dan hasil belajar siswa pada pembelajaran IPA siswa kelas V semester ganjil SDNo 2 Kapal. Peningkatan aktivitas dan hasil belajar siswa karena siswa memiliki semangat yang tinggi untuk belajar dan mengikuti proses pembelajaran, kegiatan percobaan, demonstrasindan diskusi kelompok merupakan cara belajar yang baik untuk siswa karena dalam kegiatan tersebut siswa dapat mengelola perolehan belajarnya yang didapat melalui proses belajar mengajar yang memberikan kesempatan lebih luas kepada siswa untuk mengamati, menggolongkan, meramalkan, menerapkan, merencanakan, dan mengkomunikasikannya dan menurut Suryo Subroto (1995), "Dengan mengembangkan keterampilan-keterampilan memproseskan pendekatan belajar, anak akan mampu menemukan dan mengembangkan sikap dan nilai yang dituntut seluruh irama gerak atau tindakan dalam proses balajar-mengajar sejati menciptakan kondisi cara belajar siswa aktif."

Selain itu dari pihak guru mata pelajaran sebagai fasilitator selalu memberikan semangat dan penghargaan setiap siswa yang dapat menyelesaikan tugas-tugas dengan baik dalam kelompok dan mampu menjawab pertanyaan-pertanyaan dalam tes individu. Penghargaan tersebut seperti memberi pujian, tepuk tangan dan acungan jempol. Karena dengan adanya penghargaan tersebut siswa akan merasa lebih dihargai sehingga siswa selalu ingin mengulangi perbuatannya.

Melihat peningkatan aktivitas dan hasil belajar siswa dalam pembelajaran IPA yang menerapkan pendekatan pembelajaran keterampilan proses, dapat diketahui bahwa pendekatan pembelajaran keterampilan proses ini sangat memberikan kontribusi yang positif dalam meningkatkan aktivitas dalam proses pembelajaran dan hasil belajar siswa yang optimal serta sangat baik digunakan dalam peningkatan kualitas pembelajaran di sekolah dasar.

Hasil penelitian ini sejalan dengan hasil penelitian sebelumnya yang dilakukan oleh Mashudah (2014) dan juga penelitian yang dilakukan oleh Fajar (2014) yang membuktikan bahwa penerapan Pendekatan Keterampilan Proses dapat meningkatkan hasil belajar IPA SD. Selain dua penelitian tersebut, hasil serupa juga diperoleh pada penelitian yang dilakukan oleh Juni Anggrawati (2013) bahwa penerapan model pembelajaran Nature of Science (NOS) berorientasi keterampilan proses sains berpengaruh positif terhadap hasil belajar IPA siswa. Pengaruh tersebut menunjukkan hasil yang lebih bagus saat menerapkan pembelajaran yang berorientasi pada keterampilan proses.

\section{Simpulan dan Saran}

Berdasarkanhasil penelitian tindakan kelas dan pembahasan hasil-hasil penelitian, maka dapat disimpulkan sebagai berikut. Penerapan PendekatanKeterampilan Proses dapat meningkatkan hasil belajar IPA pada siswa kelas V SD No 2 Kapal tahun pelajaran 2016/2017. Hal ini dapat dilihat dari ratarata skor hasilbelajar siswa, persentase rata-rata kelas dan ketuntasan belajar yangpada tiap siklus selalu mengalami peningkatan. Siklus I rata-rata skor siswa 69,15 meningkat pada siklus II 84,02. Persentase rata-rata kelas pada siklus I 69,15\% dan pada siklus II 84,02\%, terjadi peningkatan sebesar 14,87\% dari siklus I ke siklus II. Ketuntasan belajar pada siklus I 50\% sedangkan pada siklus II mencapai 100\%..

Berdasarkan hasil yang diperoleh pada penelitian dapat diketahui bahwa terjadi peningkatan hasil belajar siswa dalam pembelajaran IPA setelah menerapkan pendekatan pembelajaran keterampilan proses maka diajukan saran sebagai berikut. 1) Bagi siswa, membantu siswa dalam meningkatkan hasil belajar dalam mata pelajaran IPA dengan penerapan pendekatan pembelajaran keterampilan proses. Melatih siswa untuk dapat belajar bermakna, mandiri, kolaboratif dan sosial. 2) Bagi guru, hasil penelitian ini diharapkan dapat meningkatkan keterampilan dan wawasan guru dalam penerapan pendekatan pembelajaran keterampilan proses untuk meningkatkan hasil belajar IPA. Sebagai bahan pertimbangan 
bagi guru untuk menerapkan pendekatan pembelajaran keterampilan proses pada materi pelajaran lain. 3) Bagi sekolah, membantu sekolah untuk meningkatkan kualitas pendidikan dan pemberdayaan kecakapan hidup para siswanya sehingga nantinya diharapkan lebih dapat bersaing dalam kompetisi antar sekolah. Dapat dijadikan sebagai salah satu pendekatan pembelajaran dalam upaya meningkatkan mutu pendidikan. 4) Bagi peneliti lain, menambah pengalaman dan wawasan tentang penerapan pendekatan pembelajaran keterampilan proses dalam pembelajaran IPA Mendapat pengalaman tentang cara melaksanakan suatu penelitian, sehingga dalam melaksanakan penelitian berikutnya diharapkan dapat berjalan dengan lancar serta memiliki gambaran awal tentang bagaimana mengelola kelas agar siswa lebih termotivasi dalam belajar.

\section{Daftar Pustaka}

Agung, A.A Gede. (2005). Konsep dan Teknik Analisis Data Penelitian Tindakan Kelas. Singaraja: Jurusan Teknologi Pendidikan, FIP IKIP Negeri Singaraja.

Agung, A.A Gede. (2010). Evaluasi Pendidikan. Singaraja: Fakultas Ilmu pendidikan, Undiksha Singaraja

Agung, A.A Gede. (2010). Metedologi Penelitian Pendidikan. Singaraja: Aditya Media Publishing.

Aisyah, N. (2008). Pengembangan Pembelajaran Matematika SD, [Online]. Tersedia: http://getskripsi.com/search/pengertian-pendekatan-keterampilan-proses-pada-pem-belajaranmatematika/ [05 Februari 2016].

Anggarawati, Nym. Juni, I. Dw. Pt. Raka rasana, I W. Widiana. (2013). Pengaruh Model Pembelajaran NOS Berorientasi Keterampilan Proses Sains Terhadap hasil belajar IPA Kelas V SD Di Gugus XIII Kecamatan Buleleng. Mimbar PGSD 2013.

Arta Eka Wiana, Pt Juny., I Ketut Gading, Nyoman Kusmariyatni. (2017). The Application of Authentic Assessment to Improve the Learning Outcomes of Science in the fourth-grade students of SD Negeri 2 Pupuan. Journal of Education Research and Evaluation. Vol 1 No. 2.

Dimiyati. (2002). Belajar dan Pembelajaran. Jakarta. Depdikbud

Dimyati dan Mudjiono. (2002). Belajar dan Pembelajaran. Jakarta: Rineka Cipta.

Emilia, Y (2012) Penerapan Pendekatan Keterampilan Proses Melalui Metode Penemuan Terbimbing Untuk Meningkatkan Hasil Belajar Siswa Pokok Bahasan Keliling dan Luas Lingkaran di SMP Negeri 3 Panji Kelas VIII A Semester Genap Tahun Ajaran 2011/2012. [online] Tersedia: http:// repository.unej.ac.id/bitstream /handle/ 1234567 89/11838/Yeni\%20Emilia_1.pdf?sequence=1 [15 November 2015]

Fera Suliantari, Ni P., Dsk Putu Parmiti, I Wyn Widiana. (2013). Pengaruh Model Pembelajaran TSOI (Translating-Sculpting-Operationalizing-Integrating) Terhadap Hasil Belajar IPA Siswa Kelas IV di Gugus VI Kecamatan Kubu. Mimbar PGSD. Vol. 1. No. 1.

Harefa, A. O. (2011). Penerapan Pendekatan Keterampilan Proses dalam Meningkatkan Hasil Belajar Matematika SMP Negeri 1 Tuhemberua. Dalam jurnal IKIP Gunung Sitoli [Online]. Tersedia: http://ejurnal.ikipgunungsitoli.ac.id/index.php/dk/article/view/7 [02 Februari 2016].

Jayanti, Ni Komang., I Made Suarjana, I Wayan Widiana. (2014). Pengaruh Model Pembelajaran HeuristikV Berbantuan Peta Konsep Terhadap Pemahaman Konsep IPA Siswa Kelas V. Mimbar PGSD. Vol. 2. No. 1.

Jasdilla, Loli., Uus Kuswendi, Sony Ramdhani. (2017). Hasil Belajar Dan Pembelajaran Kooperatif Tipe Think Pair Share (TPS). Jurnal Pendidikan Indonesia. Vol 6. No. 1.

Julianto, dkk. (2011). Teori dan Implementasi Model-Model Pembelajaran Inovatif. Surabaya: UnesaUniversity Press

Juni a. N. Nym., I Dw Pt Raka Rasana, I Wyn Widiana., (2013). Pengaruh Model Pembelajaran Nos Berorientasi Keterampilan Proses Sains Terhadap Hasil Belajar IPA Kelas V SD di Gugus XIII Kecamatan Buleleng. Mimbar PGSD. Vol. 1. No. 1.

Juniati, Ni Wayan, I Wayan Widiana. (2017). Penerapan Model Pembelajaran Inkuiri Untuk Meningkatkan Hasil Belajar IPA. Jurnal Ilmiah Sekolah Dasar. Vol.1 (1) pp. 20-29 
Lie, A. (2004). Cooperative Learning. Mempraktekkan Cooperative Learning di Ruang-ruang Kelas. Jakarta: PT. Grasindo.

Kristiana Noviyanti, Ayu., Eunice Widyanti Setyaningtyas. (2017). Partisipasi Pembelajaran Siswa Dalam Pembelajaran Dengan Classroom Rules. Journal of Education Research and Evaluation. Vol 1 No. 2.

Mariana, I Made Alit dan Praginda Wandy. (2009). Hakikat IPA dan Pendidikan IPA untuk Guru SD. Jakarta : Pusat Pengembangan dan Pemberdayaan Pendidik dan Tenaga Kependidikan Ilmu Pengetahuan Alam (PPPPTK IPA) untuk Program Bermutu

Marjain, M. (2012) Peningkatan Ketrampilan Proses Dengan Menggunakan Metode Eksperimen Pada Mata Pelajaran IPA. [online] Vol. 2 (4), 12 halaman. Tersedia: http://jurnal.untan.ac.id/index.php/jpdpb /article/view File/1868/pdf [10 Juni 2016]

Masudah. (2014). Penerapan Pendekatan Keterampilan Proses untuk Meningkatkan Hasil Belajar IPA pada siswa kelas V SDN 1 Karangploso Kab. Malang. Malang

Oka Sugiarta, Gst Pt., I Wayan Widiana, I Dewa Kade Tastra. (2016). Penerapan Model Pembelajaran Akselerasi (Accelerated Learning) Untuk Meningkatkan Hasil Belajar Ipa Siswa Kelas V di SD N 8 Banyuning. Mimbar PGSD Vol 6 No 3 Tahun 2016. (http://ejournal.undiksha.ac.id/index.php/JPGSD/ article/view/8600).

Sadewi Widyani, Ni Luh., Ign I Wyn Suwatra, I Wayan Widiana. (2017). The Discrepancy of Curriculum 2013 in Teaching and Learning Process Based on Permendikbud No 65 of 2013 in SD Laboratorium Undiksha. Journal of Education Research and Evaluation. Vol 1 No. 2.

Santyasa, I Wayan. (2015). Validasi Dan Implementasi Model-Model Student Centered Learning Untuk Meningkatkan Penalaran Dan Karakter Siswa Sekolah Menengah Atas. Jurnal Pendidikan Indonesia. Vol 4. No. 1.

Sri Ratna Dewi, Ni Putu., I Made Citra Wibawa, Ni Luh Pande Latria Devi. (2017). Kemampuan Berpikir Kritis Dan Keterampilan Proses Dalam Pembelajaran Siklus Belajar 7e Berbasis Kearifan Lokal. Jurnal Pendidikan Indonesia. Vol 6. No. 1.

Sri Sulistiyorini. (2007). Pembelajaran IPA Sekolah Dasar dan Penerapannya dalam KTSP. Jakarta. Tiara Wacana

Sri Udayanti, IAG., Putu Nanci Riastini. (2017). Penerapan Metode Take And Give Untuk Meningkatkan Hasil Belajar IPA Siswa Kelas IVa. Jurnal Ilmiah Sekolah Dasar. Vol. 1 No. 1.

Subroto, Suryo. (1995). Proses Belajar Mengajar Di Sekolah. Jakarta. Rineka Cipta

Usman Samatowa, (2011). Pembelajaran IPA di Sekolah Dasar. Jakarta: PT Indeks.

Widiana, I Wayan. (2016). Pengembangan Asesmen Proyek Dalam Pembelajaran IPA di Sekolah Dasar. Jurnal Pendidikan Indonesia. Vol 6. No 2 tahun 2016.

Widiana, I Wayan., Gede Wira Bayu, I Nyoman Laba Jayanta. (2017). Pembelajaran Berbasis Otak (Brain Based Learning), Gaya Kognitif Kemampuan Berpikir Kreatif Dan Hasil Belajar Mahasiswa. Jurnal Pendidikan Indonesia. Vol 6. No. 1.

Widiana, I Wayan., I Nyoman Jampel. (2016). Improving Students' Creative Thinking and Achievement through the Implementation of Multiple Intelligence Approach with Mind Mapping. International Journal of Evaluation and Research in Education. Vol. 5 No. 3. 